\title{
Predictive factors for repetition of the tuberculin test after a nonreactive test in patients with HIV/AIDS
}

\author{
Líbia Cristina Rocha Vilela Moura, ${ }^{1}$ Ricardo Arraes de Alencar Ximenes, ${ }^{2}$ \\ Heloísa Ramos Lacerda, ${ }^{2}$ Demócrito Barros Miranda-Filho, ${ }^{3}$ \\ Maria Tereza Barbosa, ${ }^{4}$ Maria Rita Byington, ${ }^{5}$ \\ and Maria de Fátima Pessoa Militão Albuquerque ${ }^{6}$
}

Suggested citation

Moura LCRV, Ximenes RAA, Lacerda HR, Miranda-Filho DB, Barbosa MT, Byington MR, et al. Predictive factors for repetition of the tuberculin test after a nonreactive test in patients with HIV/AIDS. Rev Panam Salud Publica. 2012;31(2):121-8.

\begin{abstract}
Objective. The outcome of interest was repetition of the tuberculin skin test (TST) and the objectives were to estimate the rate of TST repetition, the probability of no TST repetition after 1 year, and the probability of no TST repetition at the end of the follow-up period in patients whose initial test was nonreactive. The study also set out to analyze factors associated with the time until TST repetition at two HIV/AIDS referral services that carry out the TST on a routine basis in Recife, Pernambuco, Brazil.

Methods. A cohort of HIV-positive patients who initially tested nonreactive on the TST were followed from November 2007 to February 2010. The Kaplan-Meier method was used to estimate the probability of not repeating the TST, and Cox's regression analysis was used to analyze the factors associated with time until repeating the TST. Cox's multivariate analysis was stratified according to each hospital where patients were followed, because this variable did not respect the principle of proportionality of risk.

Results. The probability of not repeating the TST for 1 year was $80.0 \%$ and at the end of the follow-up period it was $42.0 \%$. The variables that remained associated with TST repetition in the final Cox multivariate model were an age of 40 years or older, body mass index between 18.0 and 24.9 , being female, and years of schooling.

Conclusions. This study encountered a very low TST repetition rate after 1 year of followup and identified groups of individuals who should be the target of interventions aimed at repeating the TST.
\end{abstract}

Key words Tuberculin test; latent tuberculosis; HIV; Brazil.

Departamento de Medicina Tropical, Universidade Federal de Pernambuco, Recife, Brasil. Send correspondence to: Líbia Cristina Moura, mouralibia@gmail.com

2 Programa de Pós Graduação em Medicina Tropical, Universidade Federal de Pernambuco, Recife, Brasil.

3 Departamento de Medicina Clínica, Universidade de Pernambuco, Recife, Brasil.

4 Departamento de Matemática e Estatística, Universidade Federal do Rio de Janeiro, Rio de Janeiro, Brasil.
Latent infection with Mycobacterium tuberculosis is characterized by persistence of the bacillus in intracellular spaces, with slow or intermittent replication, below the levels necessary to

\footnotetext{
5 Instituto Nacional do Câncer, Rio de Janeiro, Brasil.

6 Departamento de Saúde Coletiva, Centro de Pesquisas Aggeu Magalhães, Fundação Oswaldo Cruz, Recife, Brasil.
}

produce the clinical form of the disease (1). Depending on the acquired immunity of cells, proliferation of the bacilli can be controlled, with no progression to tuberculosis disease, as occurs in $95.0 \%$ of cases. In the remaining $5.0 \%$ of infections, in which the immunological response is insufficient to stave off the proliferation of $M$. tuberculosis, primary 
tuberculosis develops, generally within 5 years after initial infection $(2,3)$.

It is estimated that a third of the world's population is infected with $M$. tuberculosis, many of whom are living with HIV and consequently run a greater risk of progressing from infection to disease (4). The period of latent M. tuberculosis infection provides an opportunity for taking measures to treat the infection, currently known as latent tuberculosis infection (LTBI) treatment in preference to the former term "chemoprophylaxis" (5), although both in effect refer to preventing future development of tuberculosis disease.

The diagnosis of LTBI was established by way of a positive tuberculin skin test (TST) associated with exclusion of tuberculosis disease (5-9).

In Brazil, the Ministry of Health has attempted to treat LTBI with isoniazid in HIV-positive patients with a TST $\geq 5$ $\mathrm{mm}$ (reactive) or with a history of contact in the home or in an institution with carriers of active pulmonary tuberculosis so long as the possibility of active tuberculosis has been ruled out. In individuals with TST $<5 \mathrm{~mm}$ (nonreactive), the test should be repeated annually; in those who are nonreactive and who are to begin antiretroviral therapy, the TST should be repeated 6 months after commencement of therapy because of the possibility of reconstitution of the immune system and recovery of the tuberculin response $(5,8,10)$.

The low sensitivity and specificity of the TST have discouraged attending physicians from carrying out the test. The need for two visits to the health service also makes it difficult for patients to adhere to the schedule $(11,12)$. Furthermore, there is some concern that treatment of LTBI with isoniazid alone may lead to the development of resistance to this drug (13). Consequently, a low frequency of applying the TST has been observed (14-16) in patients with HIV/ AIDS, who are therefore not treated for LTBI (17), even though it is a vital measure to prevent tuberculosis in this population (18-20).

Some authors believe that creating the objective conditions for incorporating TST into the routine of HIV/AIDS referral health services would be a major determining factor in ensuring effective treatment of LTBI $(11,18,21)$. These measures-the TST and LTBI treatment-have also been considered by the
Brazilian Ministry of Health to be indicators of the quality of service provided for patients with HIV / AIDS (11).

Health professionals who treat HIVpositive patients should remain on high alert for the possibility these patients will develop tuberculosis disease, as immune reconstitution syndrome may occur due to the use of highly active antiretroviral therapy (HAART) or if the patient remains at risk of exposure to M. tuberculosis in the community (22).

The literature contains studies that have analyzed repetition of the TST in patients whose initial test was nonreactive, with a view to establishing the rate of conversion of TST in patients infected with $\operatorname{HIV}(23,24)$. No studies have been found that evaluate the TST repetition rate in response to the guidelines of the World Health Organization.

The outcome of interest of this study was repetition of the TST and the objectives were to estimate the rate of TST repetition, the probability of no TST repetition after 1 year, and the probability of no TST repetition at the end of the follow-up period in patients whose initial test was nonreactive. The study also set out to analyze the factors associated with the time until TST repetition at two HIV/AIDS referral services that carry out the TST on a routine basis.

\section{CASES AND METHODS}

A prospective cohort study was carried out following up individuals living with HIV who were 18 years or older and whose initial TST test was nonreactive. The study was conducted between November 2007 and February 2010 at two referral health centers in the city of Recife, Pernambuco, Brazil.

Eligible patients were informed of the objectives of the research and, upon agreeing to participate, were asked to sign terms of informed consent. Data were collected through interviews and a specifically designed questionnaire. Another form was drawn up by the main researcher using medical records to gather further information on factors potentially associated with nonrepetition of the TST.

The TST was carried out using the Mantoux technique; trained technical staff at each referral center applied 0.1 $\mathrm{mL}$ of purified protein derivative RT 23 intradermally in the middle third of the front part of the left forearm. The test was considered to be reactive when the presence of an induration $\geq 5 \mathrm{~mm}$ was detected on a reading taken 72 hours after application of the purified protein derivative.

All patients were informed of the need to repeat the test by telephone. Lowincome patients who underwent the second test were provided travel expenses. These procedures have been routine since the TST was established at the two health centers.

The dependent variable or outcome of interest for this study was the time lapse between the first nonreactive TST and its repetition for those who repeated the test. For those patients who did not repeat the TST, the time period was from the first nonreactive TST until their last visit to the health service (i.e., their last opportunity to repeat the TST) or until the final visit made by the researchers of this study.

Variables potentially associated with repetition of the TST were analyzed in blocks: biological variables [sex, age, race, and body mass index (BMI)], socioeconomic variables (household members, steady partner, literacy, years of schooling, income, place of origin), lifestyle habits (smoking, alcohol consumption, marijuana use, cocaine use, crack use), and clinical variables (follow-up hospital, presence of opportunistic infection, presence of AIDS, time with AIDS, use of antiretroviral therapy, time on antiretroviral therapy, contact with tuberculosis, and CD4 T-lymphocyte count).

The study sample consisted of a convenience sample of individuals living with HIV over 18 years old, whose initial TST was nonreactive, between November 2007 and February 2010, at two referral health centers in the city of Recife. As there was no information from previous work on the repetition frequency of the TST, estimates were based on the Ngamvithayapong et al. study (25), which found that being female was associated with adhering to the prevention of tuberculosis in patients living with HIV. To detect differences in outcome corresponding to a relative risk of 1.32 , with a frequency of outcome in the unexposed group of $65.0 \%$, a power of $80.0 \%$, and an $\alpha$ value of $5.0 \%$, a sample of 148 individuals would be required. The number of nonreactive individuals enrolled in this study-811 individuals-exceeded the sample size estimated, thus increasing the power of the study. 
The Kaplan-Meier method was used to estimate the probability of not repeating the TST at each point in time and the log rank test was used to establish differences between the Kaplan-Meier estimates for the categories of each study variable.

Cox's proportional model was used to estimate the effect of the factors on time until achieving the outcome $(26,27)$. Results were described with the hazard ratio (HR) used as the measure of association, with a confidence interval of $95.0 \%$ for the univariate and multivariate analyses. The variables shown to be associated with the outcome in the univariate analysis with a level of statistical significance of $P<0.25$ were selected for the multivariate analysis. In order to identify the existence of variables that did not respect the assumed Cox proportionality (i.e., those whose relations to the risk of repetition constantly changed during follow-up), graphs of Schoenfeld residuals were drawn up and a test was performed to correlate these residuals with time (26).

The multivariate analysis used backward stepwise selection of variables, thereby saturating the model with all the variables associated with repetition of the TST at a level of significance of $P<0.25$ in the univariate analysis. Variables whose associations did not have a statistical significance of $P \leq 0.05$ were removed. The models were compared using the likelihood ratio test (26). The final model retained variables susceptible to public health intervention that demonstrated a statistically significant association with the outcome and those that were important from the point of view of the explanatory model. All models were adjusted using R software version 2.10.

The study was approved by the Ethics Committee for Research involving Human Beings at the Federal University of Pernambuco (SISNEP FR-067159/ CAAE-0004.1.172.106-05/CEP / CCS / UFPE 254/05).

\section{RESULTS}

Between November 2007 and February 2010, 1033 patients took the first TST. Of those tests, $811(78.5 \%)$ were nonreactive and patients were advised to repeat the test in accordance with guidelines of the Brazilian Ministry of Health (8).

Of the 811 nonreactive patients who were followed up, $314(38.7 \%)$ repeated the TST. The mean follow-up time for patients who repeated the test was 377.1 days (minimum of 152 days and maximum of 777 days). For the $497(61.3 \%)$ patients who did not repeat the TST, the mean follow-up time was 475.4 days (minimum of 91 days and maximum of 1105 days).

The median time of repeating the test (i.e., the time after which $50.0 \%$ of the patients had not repeated the TST) was 622 days (Figure 1). The probability of not repeating the TST within 365 days was $80.0 \%$, and at the end of the follow-up period (after 777 days) it was $42.0 \%$. Of the patients who were not on HAART, the probability of not repeating the TST after 1 year was $82.0 \%$, and at the end of the follow-up period it was $53.0 \%$. Among the patients on HAART, the probability of not repeating the TST after 1 year was $80.0 \%$ and $39.0 \%$ after follow-up.

Tables 1-4 show the biological, social, lifestyle, and clinical variables associated with repeating the TST in the univariate analysis.

All variables were in accordance with Cox's proportionality assumption of risk, with the exception of the "follow-up hospital" variable, as demonstrated by the significance test $\left(\chi^{2}=7.08, P=0.0078\right)$. It was thus decided to stratify the analysis according to this variable (27).

The following variables remained in the final model: sex, age, BMI, and schooling, as shown in Table 5. Patients aged 40 years or older (HR 1.47, $P=0.001)$ and with a BMI between 18.0 and 24.9 (HR 1.85, $P=0.03$ ) are more likely to repeat the TST, with a level of significance of $P<0.05$. Women (HR 1.25, $P=0.059$ ) and individuals with more than 10 years of schooling (HR $1.25, P=0.053)$ demonstrated a $25.0 \%$ greater likelihood of taking the second test. Figure 2 shows the Kaplan-Meier curves for the variables remaining in the final model.

FIGURE 1. Kaplan-Meier estimate for probability of not repeating tuberculin skin test (TST) after a first nonreactive test. Oswaldo Cruz University Hospital (HUOC), Correia Picanço Hospital (HCP)
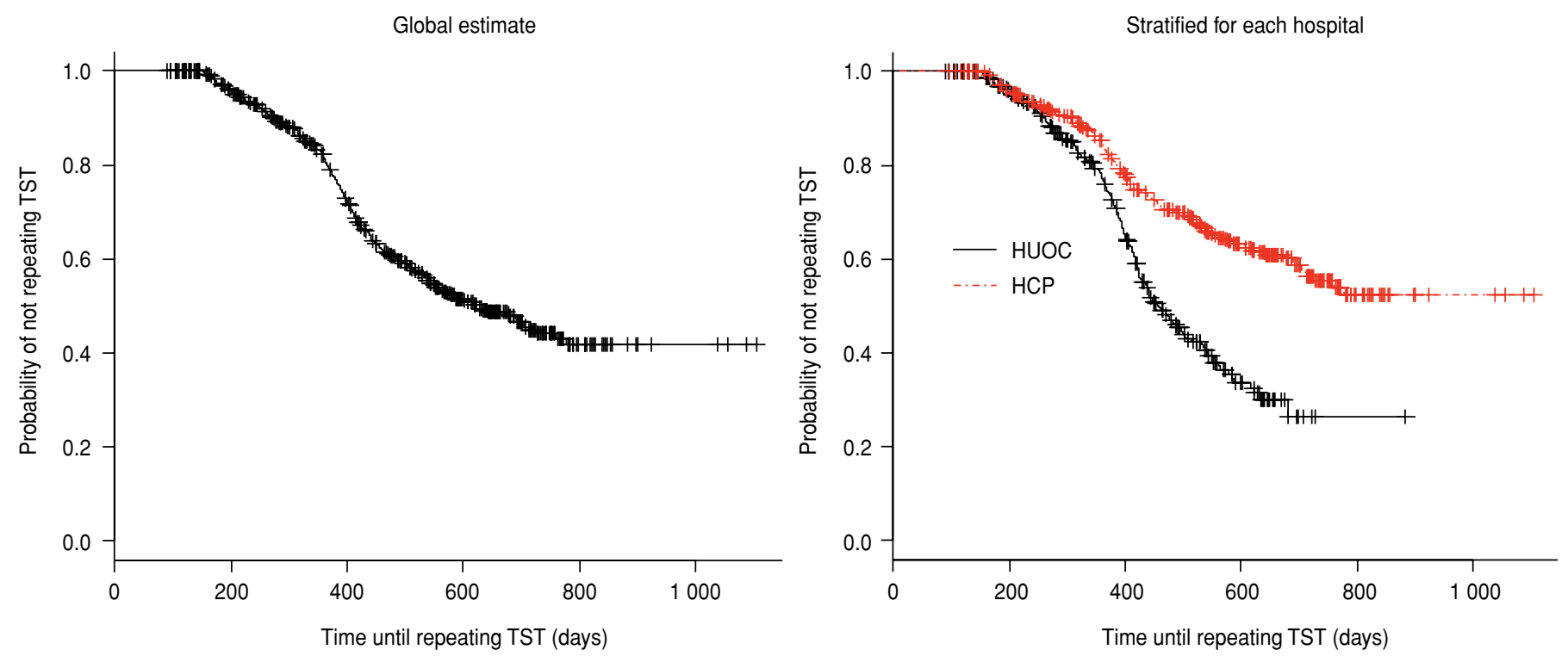
TABLE 1. Univariate analysis of biological factors associated with repetition of tuberculin skin test in HIV/AIDS patients, Recife, Pernambuco, Brazil, 2007-2010

\begin{tabular}{lccc}
\hline Biological variable & $\mathrm{HR}$ & $95 \% \mathrm{Cl}$ & $P$ \\
\hline $\begin{array}{l}\text { Sex } \\
\text { Male }\end{array}$ & 1 & $\mathrm{NA}$ & $\mathrm{NA}$ \\
$\quad$ Female & 1.26 & $1.01-1.57$ & 0.044 \\
Age (years) & & & \\
$\quad \leq 39$ & 1 & $\mathrm{NA}$ & $\mathrm{NA}$ \\
$\geq 40$ & 1.46 & $1.17-1.84$ & 0.001 \\
Race & & & \\
$\quad$ Other & 1 & $\mathrm{NA}$ & $\mathrm{NA}$ \\
White & 1.24 & $0.98-1.57$ & 0.074 \\
BMl (kg/m & & & \\
$<18.5$ & 1 & $\mathrm{NA}$ & $\mathrm{NA}$ \\
$18.5-24.9$ & 1.89 & $1.08-3.32$ & 0.02 \\
$25.0-\geq 30$ & 1.85 & $1.04-3.29$ & 0.03 \\
\hline
\end{tabular}

Notes: HR: hazard ratio, Cl: confidence interval, NA: not applicable, BMI: body mass index.

TABLE 2. Univariate analysis of socioeconomic factors associated with repetition of tuberculin skin test in HIV/AIDS patients, Recife, Pernambuco, Brazil, 2007-2010

\begin{tabular}{lccc}
\hline Socioeconomic variable & $\mathrm{HR}$ & $95 \% \mathrm{Cl}$ & $P$ \\
\hline $\begin{array}{l}\text { Household member } \\
\text { Lives alone or in shelter }\end{array}$ & 1 & $\mathrm{NA}$ & $\mathrm{NA}$ \\
$\quad \begin{array}{l}\text { Lives with family or partner } \\
\text { Steady partner }\end{array}$ & 1.04 & $0.78-1.38$ & 0.77 \\
$\quad$ No & 1 & $\mathrm{NA}$ & $\mathrm{NA}$ \\
$\quad$ Yes & 1.04 & $0.83-1.30$ & 0.76 \\
Literate & & & \\
$\quad$ No & 1 & $\mathrm{NA}$ & $\mathrm{NA}$ \\
$\quad$ Yes & 1.09 & $0.74-1.58$ & 0.66 \\
Years of schooling & & & \\
$\quad \leq 9$ years & 1 & $\mathrm{NA}$ & $\mathrm{NA}$ \\
$\quad$ 10-19 years & 1.23 & $0.99-1.54$ & 0.64 \\
Income & & & \\
$\quad 0-1$ minimum wage & 1 & $\mathrm{NA}$ & $\mathrm{NA}$ \\
$>1$ minimum wage & 1.28 & $1.02-1.61$ & 0.03 \\
Place of residence & & & \\
$\quad$ Countryside & 1 & $\mathrm{NA}$ & $\mathrm{NA}$ \\
Metropolitan region & 0.98 & $0.77-1.23$ & 0.85 \\
Recife & 0.84 & $0.53-1.23$ & 0.31 \\
\hline
\end{tabular}

Notes: HR: hazard ratio, Cl: confidence interval, NA: not applicable.

\section{DISCUSSION}

Of the 811 patients who were informed about repeating the test, in accordance with guidelines of the Brazilian Ministry of Health $(8,10)$, only $38.7 \%$ did so. The Kaplan-Meier method revealed that after 1 year of follow-up the probability of repeating the TST was only $20.0 \%$. Given that the recommendation for preventive treatment of latent tuberculosis is based on the TST, despite official guidelines, it can be understood why prevention of tuberculosis in patients with HIV/AIDS has not been achieved, as the World Health Organization shows (28).

Some authors suggest that the rates of applying the TST are low because the health services treating patients with HIV / AIDS have not incorporated the test into their routine care $(11,18,21)$. This fact has even been regarded as an indicator of service quality (11) and, since 1999, the Brazilian Ministry of Health has recommended that the TST be performed and accompanied by treatment of LTBI (10).
The results in this study suggest that incorporating the TST as a routine examination is not sufficient, even when patients' travel expenses are refunded, contrary to the findings of a previous study (29).

One issue that has been considered relevant for the control of $\mathrm{HIV} /$ tuberculosis coinfection is the need for greater interaction between tuberculosis and HIV control activities in the same health services, with a view to ensuring greater adherence on the part of patients to tuberculosis screening and the treatments available (22). This process should go beyond program coordination and should take the form of trained staff who carry out tuberculosis control activities when attending patients with HIV/AIDS. This study revealed that the sex, age, BMI, and schooling are associated with repeating the TST in the final Cox multivariate model. Patients older than 39 years are almost $50.0 \%$ more likely to repeat the TST, which may be explained by a greater awareness of older individuals for the need to follow the guidance provided by health services.

Eutrophic patients were $85.0 \%$ more likely to repeat the test than individuals with a BMI $<18.5$, which is associated with malnutrition and suggests a poorer state of health. Women and people with 10-19 years of schooling were $25.0 \%$ more likely to take a second test. It was believed that patients who repeated the TST within the expected timeframe would be those with a higher income and those who lived with others (i.e., have social support) in the city of Recife, where the two health services in the study are located. However, those factors were not associated with repetition of the TST. Factors relating to lifestyle and habits likewise showed no association with repetition of the TST.

Elzi et al. found that the TST was performed less frequently among patients receiving antiretroviral therapy than among those not receiving it $(P<0.001)$ (12). In this study, the use of HAART was not associated with repetition of the TST. This finding means that, in the population studied, patients who consult the health service for other reasons may not be given the TST.

These results show that there is not an adequate level of adherence to repetition of the TST when it is recommended, even though the test has been incorporated into the routines of the 
TABLE 3. Univariate analysis of lifestyle habits associated with repetition of tuberculin skin test in HIV/AIDS patients, Recife, Pernambuco, Brazil, 2007-2010

\begin{tabular}{lccc}
\hline \multicolumn{1}{c}{ Lifestyle variable } & $\mathrm{HR}$ & $95 \% \mathrm{Cl}$ & $P$ \\
\hline Alcohol & & & \\
$\quad$ Drinker & 1 & $\mathrm{NA}$ & $\mathrm{NA}$ \\
$\quad$ Nondrinker & 1.01 & $0.80-1.27$ & 0.94 \\
$\begin{array}{l}\text { Smoker } \\
\text { Yes (current or former smoker) }\end{array}$ & 1 & $\mathrm{NA}$ & $\mathrm{NA}$ \\
$\quad$ No & 1.18 & $0.95-1.48$ & 0.13 \\
Marijuana use & & $\mathrm{NA}$ & $\mathrm{NA}$ \\
$\quad$ Yes & 1 & $0.99-1.75$ & 0.05 \\
$\quad$ No & 1.32 & $\mathrm{NA}$ & $\mathrm{NA}$ \\
Crack use & & $0.75-2.83$ & 0.26 \\
Yes & 1.46 & $\mathrm{NA}$ & $\mathrm{NA}$ \\
No & & $0.65-1.69$ & 0.84 \\
Cocaine use & 1 & & \\
Yes & 1.05 & & \\
No & & &
\end{tabular}

Notes: HR: hazard ratio, Cl: confidence interval, NA: not applicable.

TABLE 4. Univariate analysis of clinical factors associated with repetition of tuberculin skin test in HIV/AIDS patients, Recife, Pernambuco, Brazil, 2007-2010

\begin{tabular}{|c|c|c|c|}
\hline Clinical variable & HR & $95 \% \mathrm{Cl}$ & $P$ \\
\hline \multicolumn{4}{|l|}{ Hospital } \\
\hline HUOC & 1 & NA & NA \\
\hline $\mathrm{HCP}$ & 0.47 & $0.38-0.60$ & $<0.001$ \\
\hline \multicolumn{4}{|l|}{ Opportunistic infection } \\
\hline No & 1 & NA & NA \\
\hline Yes & 0.92 & $0.73-1.16$ & 0.46 \\
\hline \multicolumn{4}{|l|}{ On ARVT } \\
\hline \multicolumn{4}{|l|}{ No } \\
\hline Yes & 1.26 & $0.93-1.70$ & 0.13 \\
\hline \multicolumn{4}{|l|}{ Length of time on ARVT } \\
\hline$\geq 1$ year & 1 & NA & NA \\
\hline$<1$ year & 0.89 & $0.64-1.24$ & 0.50 \\
\hline \multicolumn{4}{|l|}{ Contact with TB } \\
\hline No & 1 & NA & NA \\
\hline Yes & 1.02 & $0.80-1.31$ & 0.85 \\
\hline \multicolumn{4}{|l|}{ AIDS } \\
\hline No & 1 & NA & NA \\
\hline Yes & 1.01 & $0.75-1.37$ & 0.93 \\
\hline \multicolumn{4}{|l|}{ Length of time with AIDS } \\
\hline$\geq 1$ year & 1 & NA & NA \\
\hline$<1$ year & 0.88 & $0.62-1.24$ & 0.46 \\
\hline \multicolumn{4}{|c|}{ CD4 cell count up to 360 days } \\
\hline$<200 \mathrm{cells} / \mathrm{mm}^{3}$ & 1 & NA & NA \\
\hline$\geq 200 \mathrm{cell} / \mathrm{s} \mathrm{mm}^{3}$ & 1.37 & $0.97-1.92$ & 0.06 \\
\hline
\end{tabular}

Notes: HR: hazard ratio, Cl: confidence interval, HUOC: Oswaldo Cruz University Hospital, NA: not applicable, HCP: Correia Picanço Hospital, ARVT: antiretroviral, TB: tuberculosis.

health services where the study was carried out. It is striking that there was a statistical difference in the likelihood of not repeating the test between the two health centers studied $(P<0.001)$, which suggests the importance of involving the team as a whole in tuberculosis control actions. Of particular importance is the role of medical assistants in this process, as these individuals decide whether to initiate treatment of latent tuberculosis (30) and are thus responsible for encouraging patients to take the TST when recommended. The important role of nurses should also be stressed, as they are generally the ones who apply the TST and schedule a patient's return visit. A rise in adherence to TST from $37.0 \%$ to
$74.0 \%$ was identified when, in addition to food vouchers, patients living with HIV also received a nursing education session (31). The role of the nurse has been shown to be especially important in screening for tuberculosis and in providing advice and education for patients attending adult emergency services, including those with HIV / AIDS (32).

The identification of patients for whom treatment for LTBI is recommended should be a priority when treating patients living with HIV. The guidelines stress the need to carry out the TST and treatment for LTBI, but it is unclear how these procedures have been implemented and there appears to have been insufficient adherence to these recommendations (15).

The results presented here provide evidence of what the literature describes as the "law of inverse care" (33), in which the availability of adequate medical care tends to vary inversely with the needs of the population served. This study demonstrates this contradiction insofar as the groups most at risk for tuberculosis, and thus those who should be a priority for repetition of the TST, were those who showed the least likelihood of taking the test. In other words, adherence to the TST was less frequent among men, young people, and individuals with fewer years of schooling, which are factors associated with developing tuberculosis $(34,35)$.

This result leads us to question why the provided service is not reaching the groups who most need action to prevent tuberculosis. The obstacles to tuberculosis-prevention activities need to be addressed and overcome to ensure that patients coinfected with HIV and tuberculosis are attended and treated adequately and in a timely fashion. The need to treat LTBI is unquestionable in developing countries, where tuberculosis remains the principal cause of morbidity and mortality among people living with HIV/AIDS (36), even after the introduction of HAART (37).

This study had the limitations of an observational study conducted in two health centers. However, because it was conducted during routine patient care, the operational research has the advantage of identifying existing obstacles for not complying with the recommendations of official health agencies. Because it was a prospective cohort study, it was possible to use methods of survival 
TABLE 5. Multivariate analysis, stratified by hospital, of factors associated with repetition of tuberculin skin test, Recife, Pernambuco, Brazil, 2007-2010

\begin{tabular}{lccc}
\hline \multicolumn{1}{c}{ Variable } & $\mathrm{HR}$ & $95 \% \mathrm{Cl}$ & $P$ \\
\hline $\begin{array}{l}\text { Sex } \\
\text { Male }\end{array}$ & 1 & $\mathrm{NA}$ & $\mathrm{NA}$ \\
$\quad$ Female & 1.25 & $0.99-1.57$ & 0.059 \\
Age (years) & & & \\
$\quad \leq 39$ & 1 & $\mathrm{NA}$ & $\mathrm{NA}$ \\
$\geq 40$ & 1.47 & $1.15-1.88$ & 0.001 \\
$\mathrm{BMl}\left(\mathrm{kg} / \mathrm{m}^{2}\right)$ & & & \\
$<18.5$ & 1 & $\mathrm{NA}$ & $\mathrm{NA}$ \\
$18.0-24.9$ & 1.85 & $1.05-3.25$ & 0.031 \\
$25.0-30$ & 1.67 & $0.93-2.97$ & 0.081 \\
Years of schooling & & & \\
$<10$ years & 1 & $\mathrm{NA}$ & $\mathrm{NA}$ \\
$10-19$ years & 1.25 & $0.99-1.57$ & 0.053 \\
\hline
\end{tabular}

Notes: HR: hazard ratio, Cl: confidence interval, NA: not applicable, BMl: body mass index. analysis to estimate the TST repetition rate and the Cox proportional regression to identify the factors associated with not repeating the TST.

This study encountered a very low TST repetition rate after 1 year of followup, with no statistically significant difference between groups of patients using and not using HAART. The analysis identified groups of individuals who should be targeted for interventions aimed at ensuring that the TST is repeated after an initial nonreactive test in individuals living with HIV.

A recent study continues to point to the benefits of LTBI treatment for people living with HIV, regardless of whether they are on HAART and regardless of the

FIGURE 2. Kaplan-Meier estimate for probability of not repeating tuberculin skin test (TST) after a first nonreactive test for variables that remained in the final multivariate model
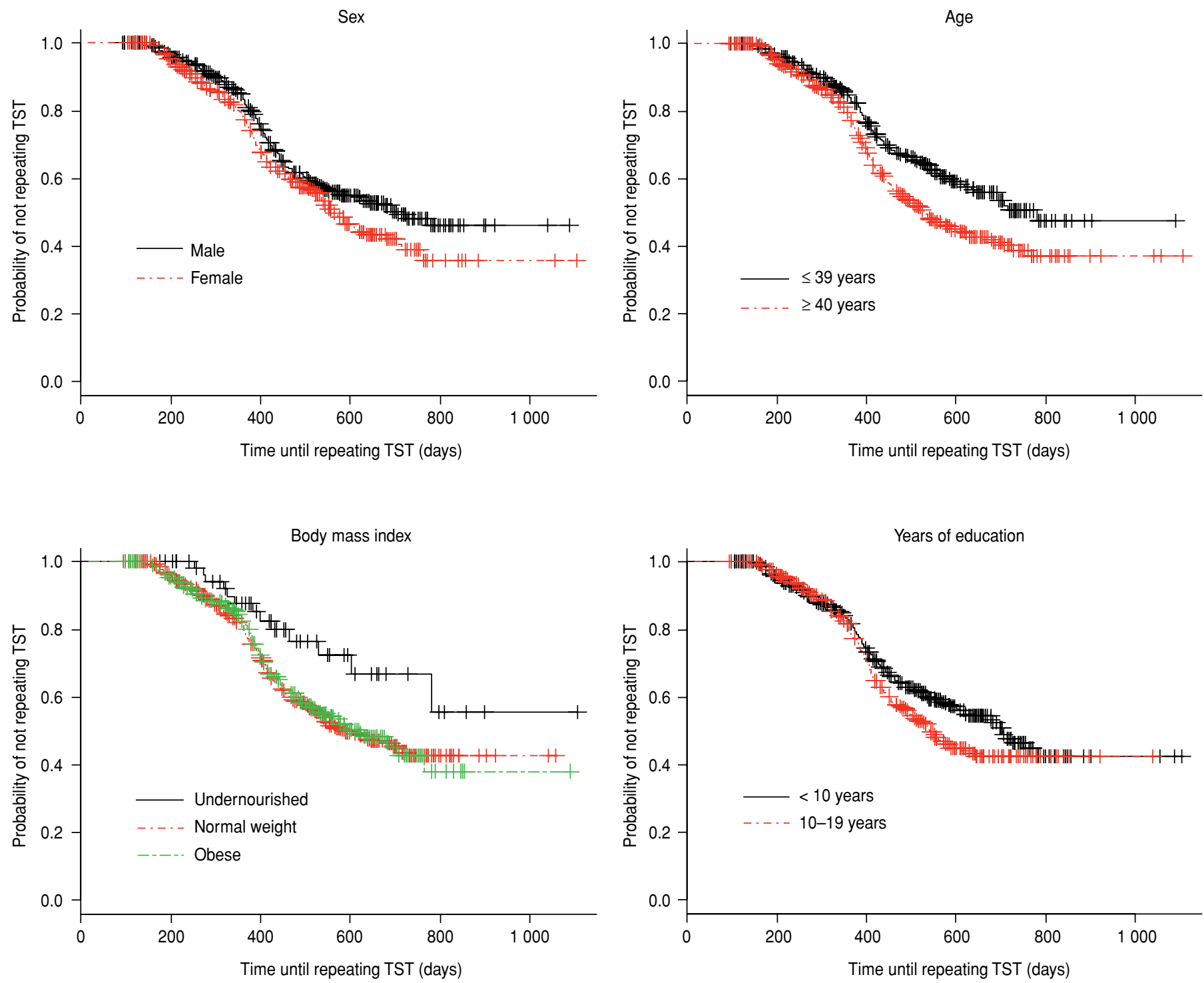
result of the TST. ${ }^{7}$ However, the debate continues on introducing LTBI treatment and on the regimens and strategies to be

\footnotetext{
7 Golub JE, Saraceni V, Cohn S, Pacheco AG, Moulton LH, Cavalcante SC, Efron A, Chaisson RE, Durovni B. Value of the tuberculin skin testing for isoniazid preventive therapy for HIV-infected patients [conference presentation]. At: AIDS 2010: XVIII International AIDS Conference, Vienna, 18-23 July, 2010.
}

used, as they are considered complex and depend on local economic and logistic questions (38). If the effectiveness of LTBI treatment can be shown regardless of the result of the TST and there is no improvement in the difficulties in applying the test, the recommendations should be reviewed and measures should be taken to ensure that necessary changes are made.
Acknowledgment. The authors are grateful for the support received from the Brazilian Ministry of Health/ STD/ AIDS/UNESCO Program (CSV 182/06 Project "A Clinical and Epidemiological Study of HIV/Tuberculosis Co-infection in Recife").

\section{REFERENCES}

1. Manabe YC, Bishai WR. Latent Mycobacterium tuberculosis-persistence, patience and winning by waiting. Nat Med. 2000;6(12):1327-9.

2. Almeida P, Oliveira MM, Hinrichsen SL, Kawassaki AM, Lima EHM. Tuberculose. In: Hinrichsen SL, ed. Doenças infecciosas e parasitárias. Rio de Janeiro: Guanabara Koogan; 2005. Pp. 281-96.

3. Sharma SK, Mohan A, Kadhiravan T. HIVTB co-infection: epidemiology, diagnosis \& management. Indian J Med Res. 2005;121(4): $550-67$.

4. World Health Organization. The global plan to stop tuberculosis. Geneva: WHO; 2003.

5. Conde MB, Melo FAF, Marques AMC, Cardoso NC, Pinheiro VGF, Dalcin PTR, et al. III diretrizes para tuberculose da sociedade Brasileira de pneumologia e tisiologia. J Bras Pneumol. 2009;35(10):1018-48.

6. Kunst H. Diagnosis of latent tuberculosis infection: the potential role of new technologies. Respir Med. 2006;100(12):2098-106.

7. Joint Tuberculosis Committee of British Thoracic Society. Control and prevention of tuberculosis in the United Kingdom: code of practice 2000. Thorax. 2000;55(11):887-901.

8. Brasil Ministério da Saúde. Tuberculose. Guia de vigilância epidemiológica. Brasília: Brasil Ministério da Saúde, Secretaria de Vigilância Sanitária; 2009.

9. Girardi E, Antonucci G, Vanacore P, Libanore M, Errante I, Matteelli A, et al. Impact of combination antiretroviral therapy on the risk of tuberculosis among persons with HIV infection. AIDS. 2000;14(13):1985-91.

10. Ministério da Saúde, Secretaria de Vigilância em Saúde, Programa Nacional de DST e Aids. Recomendações para terapia anti-retroviral em adultos e adolescentes infectados pelo HIV 2007/2008. Documento preliminar. Brasília: Brasil Ministério da Saúde, Secretaria de Vigilância em Saúde; 2007.

11. Jamal FF, Moherdaui F. Tuberculose e infecção pelo HIV no Brasil: magnitude do problema e estratégias para o controle. Rev Saúde Pública. 2007;41(Suppl 1):104-10.

12. Elzi L, Schlegel M, Weber R, Hirschel B, Cavassini M, Schmid P, et al. Reducing tuberculosis incidence by tuberculin skin testing, preventive treatment, and antiretroviral therapy in an area of low tuberculosis transmission. Clin Infect Dis. 2007;44(1):94-102.

13. Halsema CL, Fielding KL, Chihota VN, Russell EC, Lewis JJ, Churchyard GJ, et al. Tuberculosis outcomes and drug suscepti- bility in individuals exposed to isoniazid preventive therapy in a high HIV prevalence setting. AIDS. 2010;24(7):1051-5.

14. Nogueira CT, Abrantes JL, Frauches DO, Borges LHB. Abordagem profilática contra tuberculose em pacientes infectados pelo HIV em serviço ambulatorial de hospital filantrópico. J Bras Doenças Sex Transm. 2009;21(4): $158-62$.

15. Golub JE, Saraceni V, Cavalcante SC, Pacheco AG, Moulton LH, King BS, et al. The impact of antiretroviral therapy and isoniazid preventive therapy on tuberculosis incidence in HIV-infected patients in Rio de Janeiro, Brazil. AIDS. 2007;21(11):1441-8.

16. Días A, Díez M, Bleda MJ, Aldamiz M, Camafort M, Camino X, et al. Factores asociados con la no realización de la prueba de la tuberculina en una cohorte de pacientes VIH positivos. Enferm Infecc Microbiol Clin. 2010; 28(4):215-21.

17. World Health Organization. Guidelines for intensified tuberculosis case-finding and isoniazid preventive therapy for people living with HIV in resource constrained settings. Geneva: WHO; 2011.

18. Grant AD, Charalambous S, Fielding KL, Day JH, Corbett EL, Chaisson RE, et al. Effect of routine isoniazid preventive therapy on tuberculosis incidence among HIV-infected men in South Africa: a novel randomized incremental recruitment study. JAMA. 2005; 293(22):2719-25.

19. Smieja MJ, Marchetti CA, Cook DJ, Smaill FM. Isoniazid for preventing tuberculosis in nonHIV infected persons. Cochrane Database Syst Rev. 2000;(2):CD001363.

20. Woldehanna S, Volmink J. Treatment of latent tuberculosis infection in HIV infected persons. Cochrane Database Syst Rev. 2004;(1): CD000171.

21. World Health Organization, Global Tuberculosis Programme, and Joint United Nations Programme on HIV/AIDS. Policy statement on preventive therapy against tuberculosis in people living with HIV. Meeting report. Geneva: WHO; 1998.

22. Long R, Houston S, Hershfield E. Recommendations for screening and prevention of tuberculosis in patients with HIV and for screening for HIV in patients with tuberculosis and their contacts. Can Med Assoc J. 2003;169(8): 789-91.

23. Girardi E, Palmieri F, Zaccarelli M, Tozzi V, Trotta MP, Selva C, et al. High incidence of tuberculin skin test conversion among HIV- infected individuals who have a favourable immunological response to highly active antiretroviral therapy. AIDS. 2002;16(14):1976-9.

24. Narita M, Ashkin D, Hollender ES, Pitchenik AE. Paradoxical worsening of tuberculosis following antiretroviral therapy in patients with AIDS. Am J Respir Crit Care Med. 1998; 158(1):157-61.

25. Ngamvithayapong J, Uthaivoravit W, Yanai $\mathrm{H}$, Akarasewi P, Sawanpanyalert P. Adherence to tuberculosis preventive therapy among HIV-infected persons in Chiang Rai, Thailand. AIDS. 1997;11(1):107-12.

26. Carvalho MS, Andreozzi VL, Codeço CT, Barbosa MTS, Shimakura SE. Análise de sobrevida: teoria e aplicações em saúde. 20th ed. Rio de Janeiro: Editora Fiocruz; 2005. Pp. $175-256$

27. Kleinbaum DG, Klein M. Survival analysis: a self-learning text. 2nd ed. New York: Springer Science; 2005.

28. World Health Organization. Interim policy on collaborative TB/HIV activities. Geneva: WHO; 2004.

29. Lorvick J, Thompson S, Edlin BR, Kral AH, Lifson AR, Watters JK. Incentives and accessibility: a pilot study to promote adherence to TB prophylaxis in a high-risk community. J Urban Health. 1999;76(4):461-7.

30. de Pinho AMF, Santoro-Lopes G, Harrison $\mathrm{LH}$, Schechter M. Chemoprophylaxis for tuberculosis and survival of HIV-infected patients in Brazil. AIDS. 2001;15(16):2129-35.

31. Chaisson RE, Keruly JC, McAvinue S, Gallant JE, Moore RD. Effects of an incentive and education program on return rates for PPD test reading in patients with HIV infection. J Acquir Immune Defic Syndr Hum Retrovirol. 1996;11(5):455-9.

32. Kirsch DT, Chanmugam A, Keyl P, Regan LA, Shahan J, Hexter DA, et al. Feasibility of an emergency department-based tuberculosis counseling and screening program. Acad Emerg Med. 1999;6(3):224-31.

33. Hart JT. The inverse care law. Lancet. 1971; 1(7696):405-12

34. Godoy P, Castilla J, Rullan JV. Incidencia y factores de riesgo de la asociación del sida y la tuberculosis en España. Med Clin (Barc). 1998; 110(6):205-8.

35. de Alencar Ximenes RA, de Fátima Pessoa Militão de Albuquerque M, Souza WV, Montarroyos UR, Diniz GT, Luna CF, et al. Is it better to be rich in a poor area or poor in a rich area? A multilevel analysis of a 
case-control study of social determinants of tuberculosis. Int J Epidemiol. 2009;38(5): $1285-96$.

36. Mayer KH, Dukes Hamilton C. Synergistic pandemics: confronting the global HIV and tuberculosis epidemics. Clin Infect Dis. 2010; 50(Suppl 3):567-70.
37. Grinsztejn B, Veloso VG, Friedman RK, Moreira RI, Luz PM, Campos DP, et al. Early mortality and cause of deaths in patients using HAART in Brazil and the United States. AIDS. 2009;23(16):2107-14.

38. Johnson JL, Okwera A, Hom DL, Mayanja H, Mutuluuza Kityo C, Nsubuga P, et al. Dura- tion of efficacy of treatment of latent tuberculosis infection in HIV-infected adults. AIDS 2001;15(16):2137-47.

Manuscript received on 21 January 2011. Revised version accepted for publication on 1 August 2011.
RESUMEN

Factores predictivos para la repetición de la prueba de la tuberculina después de un resultado no reactivo en pacientes con infección por el VIH/sida

\section{Palabras clave \\ Prueba de tuberculina; tuberculosis latente; VIH; Brasil.}

Objetivo. El resultado principal de interés fue la repetición de la prueba de la tuberculina (PT) y los objetivos fueron calcular la tasa de repetición de la PT, la probabilidad de no repetir la PT después de un año y la probabilidad de no repetir la PT al final del período de seguimiento en los pacientes cuya prueba inicial fue no reactiva. En el estudio también se analizaron los factores asociados con el tiempo hasta la repetición de la PT en dos servicios de referencia de infección por el VIH/sida que llevan a cabo la PT de manera sistemática en Recife, Pernambuco, Brasil.

Métodos. Entre noviembre del 2007 y febrero del 2010 se siguió a una cohorte de pacientes seropositivos para el VIH con una PT inicialmente no reactiva. Para calcular la probabilidad de no repetir la PT se empleó el método de Kaplan-Meier, y para analizar los factores asociados con el tiempo hasta la repetición de la PT se usó el análisis de regresión de Cox. El análisis multifactorial de Cox se estratificó conforme a cada hospital donde se seguía a los pacientes, dado que esta variable no respetaba el principio de proporcionalidad del riesgo.

Resultados. La probabilidad de no repetir la PT durante un año fue de $80,0 \%$ y hacia el final del período de seguimiento fue de $42,0 \%$. Las variables asociadas con la repetición de la PT en el modelo multifactorial de Cox final fueron una edad de 40 años o más, un índice de masa corporal de 18,0 a 24,9, el sexo femenino y los años de escolaridad.

Conclusiones. En este estudio se encontró una tasa de repetición de la PT muy baja después de un año de seguimiento y se identificó a los grupos de individuos que deben ser los destinatarios de las intervenciones dirigidas a repetir la prueba de la tuberculina. 